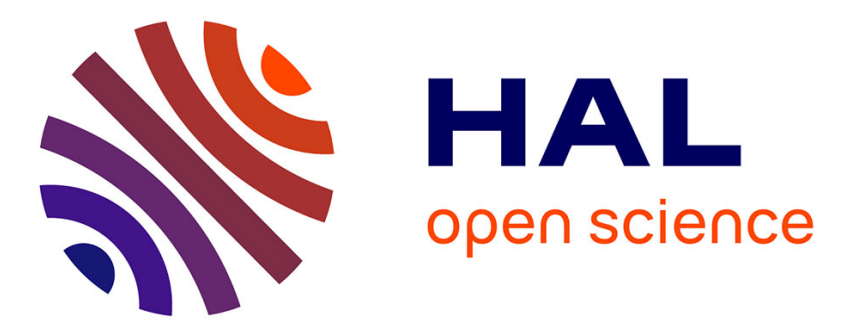

\title{
The Basic Analyze of Formation and Current Condition of Securities Market in Republic of Armenia
}

\author{
Koryun Atoyan
}

\section{To cite this version:}

Koryun Atoyan. The Basic Analyze of Formation and Current Condition of Securities Market in Republic of Armenia. International Conference on Trends in Economics, Humanities and Management (ICTEHM'15), Mar 2015, Singapore, Singapore. pp.108-111, 10.15242/icehm.ed0315109 . hal03283589

\section{HAL Id: hal-03283589 \\ https://hal.science/hal-03283589}

Submitted on 12 Jul 2021

HAL is a multi-disciplinary open access archive for the deposit and dissemination of scientific research documents, whether they are published or not. The documents may come from teaching and research institutions in France or abroad, or from public or private research centers.
L'archive ouverte pluridisciplinaire HAL, est destinée au dépôt et à la diffusion de documents scientifiques de niveau recherche, publiés ou non, émanant des établissements d'enseignement et de recherche français ou étrangers, des laboratoires publics ou privés. 


\title{
The Basic Analyze of Formation and Current Condition of Securities Market in Republic of Armenia
}

\author{
Koryun Atoyan
}

\begin{abstract}
Formation and future development of securities market in Republic of Armenia is one of the main components of market economy.

For now securities market in Armenia is in a stage of development and the most important issue became attraction of available money resources /cash assets/.

One of the basic characteristics resulted in legislation of RA is that the securities testifies to presence of property attitudes and, that the owner has the certain rights fixed in them. When securities is in circulation, the owner of the rights concedes to their new owner, and transferring the securities, the rights fixed in it and are transferred all to a duty.

The securities market is the major component of the financial market of any country. The pace and extent of development indicate the degree of economic development of the country, as well as the whole society. This is also evidenced by published market indexes more or less developed countries, which in its content are characteristic of the economic development.
\end{abstract}

Keywords-Securities market, shares, public bonds, market capitalization, issuer.

\section{INTRODUCTION}

$\mathrm{T}$ $\mathrm{HE}$ issue of improvement securities market regulation is one of the basic directions of development of a securities market. Experience of the countries with the developed financial markets shows that issue of state regulation as a whole cannot separately develop from depth and a level of development of market attitudes.

The securities market of the developed countries had no principles of restricted regulation and high-grade management from the state. Operations on securities market were more often perceived as gambling, the prices and profits of dealers as exclusively speculative phenomenon, and participation of the state was reduced to a minimum. In due course volumes of securities in circulation have considerably grown and have started to influence economy considerably.

Since 1996 cooperation between RA and Agency for International Development (USAID) has begun. In this period of time in the Republic of Armenia initiated unification of public policy formation stock. A major principle of the first

Koryun Atoyan is with the Armenian State University of Economics, Yerevan, 0025. Armenia (phone: $+37491-211917$, fax: $+37410-593422$. Email: Prof_Mkhitaryan@yahoo.com. program was maintenance of economic growth of the country on means of centralization of financial assets, their productive distribution and rational use, and also maintenance of a legal protection for residents and non-residents. Steps in a direction of attraction of investments, economic interests of the state, attraction of shareholders, protection of the rights of shareholders and investors, creations of conditions for a diligent competition and restriction of monopoly have been undertaken [1].

The decision of such questions, as increments of the list of financial tools for trade (first of all, connected with privatization) concentration of the financial markets for increase in volume of real transactions at trading platforms was necessary. The securities market should become transparent; clearing center of transactions of sale and purchase of securities between all participants should become constantly operating system for all kind of calculations and estimations.

Subsequently, measures were taken settlement, which were aimed at protecting the rights of shareholders, investors and the protection of property, providing dynamic control, as well as in the direction of becoming a productive and competitive market, which could accumulate funds for innovative development and promote the long flow of financial capital in the country [2]. Have been solved such problems, as

1. Creating the necessary conditions for increasing volumes of investment and domestic savings, mainly focus on in collective forms of investment (investment funds, not public pension funds and insurance companies).

2. While raising funds, the introduction of incentive mechanisms to exit the stock market subjects of economic activity

3. Development state and market mechanisms of the control over emitters for prevention of infringements of interests of investors,

4. Preservation and encouragement of demand on a securities market through preservation of the rights of investors,

5. Encouragement of a corresponding level of preservation of corporate management and disclosing of the information.

It is necessary to note, that the securities market existed and during Soviet Union's time in the form of trade credits. However during this period the securities market had the 
limited character, carried out more likely functions of redistribution, than mobilization of financial assets as the stock exchange and the market did not exist where securities were and on sale.

Occurrence of a securities market, formation and the beginning of functioning of a stock exchange and the exchange tenders, are logic continuation of privatization of a state ownership. In Armenia in consequence of mass privatization of the state enterprises were generated new economic-legal relations, and also following institutional structures

- Corporate sphere of economy,

- A stock exchange of corporate securities and OTC markets,

- A group of large proprietors and a wide spectrum of fine proprietors.

On the securities market of Armenia as the basic emitters acting the open joint-stock companies and the government.

According to Civil Code of RA bonds, the cheques, simple and translation bills, shares, the consignments, the bank certificates, simple warehouse certificates and other documents which according to the law on securities concern to securities. The following securities are classified in the general groups

- Shares and bonds are investment securities,

- The cheques, promissory notes and transfer notes are payment securities,

- The consignments, double warehouse certificates and simple warehouse certificates are title securities.

In circulation PA there are also other securities

- The future contract is a standardized contract between two parties to buy or sell a specified asset of standardized quantity and quality for a price agreed upon today (the futures price) with delivery and payment occurring at a specified future date, the delivery date. The contracts are negotiated at a futures exchange, which acts as an intermediary between the two parties. The party agreeing to buy the underlying asset in the future, the "buyer" of the contract, is said to be "long", and the party agreeing to sell the asset in the future, the "seller" of the contract, is said to be "short". • The forward contract, which one party undertakes (usually on the securities) when due hereunder, under the fixed price at present transactions to get or sell to other party any goods, including the securities or currency,

- The forward contract or simply a forward is a nonstandardized contract between two parties to buy or to sell an asset at a specified future time at a price agreed upon today.[1] This is in contrast to a spot contract, which is an agreement to buy or sell an asset today. The party agreeing to buy the underlying asset in the future assumes a long position, and the party agreeing to sell the asset in the future assumes a short position. The price agreed upon is called the delivery price, which is equal to the forward price at the time the contract is entered into.

- The option contract, An option contract, or simply option, is defined as "a promise which meets the requirements for the formation of a contract and limits the promisor's power to revoke an offer." An option contract is a type of contract that protects an offeree from an offeror's ability to revoke the contract. Consideration for the option contract is still required as it is still a form of contract. Typically, an offeree can provide consideration for the option contract by paying money for the contract or by providing value in some other form such as by rendering other performance or forbearance.

It is necessary to note, that the priority role of Armenia on a securities market from year to year grows. The volume of the market of the public bonds considerably exceeds the sizes of the market of corporate securities.

Now currently in our country most actively are in turnover process short-term and intermediate term public bonds. Release of bonds has been begun in August, 1995 then periodically new releases from Government of RA and Ministries of Finance were carried out. We shall note also, that for now distribution of bonds is carried out also through " NASDAQ OMX ARMENIA ".

On a bond market the Central bank of Armenia carries out registration of the property right to bonds, executes functions of the decision of mutual duties in the operations which are carried out by bonds, cheques and the account of duties at supply of bonds. It means that the Central bank, actually, on a bond market carries out functions of clearing bank.

As of 2012 in the market of the state bonds, the subject, the carried out transactions, from professional persons, became short-term state bonds, the state bonds of intermediate term repayment, and also release and distribution of the state longterm credits.

Government bonds are issued by the Ministry of Finance of RA on behalf of the Republic of Armenia and are insured by the whole property of the country. Government bonds are issued for the purpose of financing state deficit. The Ministry issues state (treasury) T-bills for 1 year period, medium term coupon notes (MTCN) from 15 months to 5 year and long term coupon bonds (LTCB) from 6 to 30 years maturity period. Saving bonds from 3 months to 25 year maturity period as well issued, which are non commercial bonds and may be sold only to individuals through the Treasury Direct. The rest are commercial bonds, which can be acquired by legal entities. Government bonds are allocated through close auctions only with the participation of previously elected major dealers who satisfy certain criteria. Here you can find frequently updated information on upcoming yield, maturity period and issue of bonds.

Market makers are important players in the marketplace, as they support the liquidity of securities by providing continuous bid and ask quotations. Holders of securities that have appointed market makers can be confident that they can sell their holdings at any time. Through enhancing the liquidity of securities, market makers contribute to the maintenance of an efficient and orderly market.

The market maker concept was introduced on the Armenian Stock Exchange, now NASDAQ OMX Armenia, in December 2006. Market making status can be obtained by any exchange 
member who complies with the provisions of NASDAQ OMX Armenia Market Maker Rules. Market makers on NASDAQ OMX Armenia are required to:

- provide continuous two-sided quotations for their appointed issue(s) from starting within 10 minutes after the opening of the trading session up until the close of trading;

- within three minutes after the matching of buy and/or sell order, place new two sided quotations;

- ensure the minimum quotation volume defined for their appointed securities, with partial execution stated as a condition (minimum quotation value is defined according to the procedure outlined in Market Maker Rules, depending on the market capitalization of the issuer);

- provide two-sided quotations within the spread limits envisaged by NASDAQ OMX Armenia rules;

- conclude at least one transaction per every three changes in two-sided quotations for each class of their appointed issues occurred during the same trading session.

\section{THE GOVERNMENT INTERMEDIATE TERM COUPON BONDS WITH PARTIAL REPAYMENTS}

Currently on the market of securities in circulation are mainly issued bonds, and their prevailing part has been let out because of privatizations of the state enterprises.

The securities which are being in circulation in Armenian securities market are shares of joint-stock companies. We shall note, that the resulting figures, even in developing countries is very low.

Moreover, at a very low level is the approximate market capitalization (taken to calculate the state of a particular component of the day-on the basis of the formation of market prices of stocks throughout the day). Correlation coefficient of GDP for the last 4 years not exceeding $4.5 \%$. In the theoretical part of the work carried out calculations related to stock market capitalization, which is an important indicator in terms of economic growth. Now calculate the figure for the Republic of Armenia and Georgia.

TABLE I

Percentage Parity Between Gross National Product And Exchange CAPITALIZATION IN 2014

\begin{tabular}{|lllll|}
\hline $\begin{array}{l}\text { The } \\
\text { country }\end{array}$ & $\begin{array}{l}\text { The name of } \\
\text { a stock } \\
\text { exchange }\end{array}$ & $\begin{array}{l}\text { Volume of } \\
\text { gross national } \\
\text { product } \\
\text { (Billion. US } \\
\text { Dollar) }\end{array}$ & $\begin{array}{l}\text { Market } \\
\text { capitalization } \\
\text { (Billion. US } \\
\text { Dollar) }\end{array}$ & $\begin{array}{l}\text { Percentage parity } \\
\text { between gross } \\
\text { national product and } \\
\text { exchange } \\
\text { capitalization }\end{array}$ \\
Georgia & GSX & $\begin{array}{l}14,47 \\
10,1\end{array}$ & 795,6 & $154.9 \%$ \\
Armenia & $\begin{array}{l}\text { NASDAQ } \\
\text { OMX } \\
\text { Armenia }\end{array}$ & & 43,5 & $104.3 \%$ \\
\hline
\end{tabular}

As we see, the percentage parity between gross national product and exchange capitalization has made in Georgia 154, $9 \%$, and in Armenia - 104, $3 \%$.

The difference between the indices of Armenia and Georgia are manifest in question both in absolute and relative terms. The reason is that Armenia is hardly surviving. But this phenomenon has its justification. The fact that the Republic of Armenia is at a disadvantage in terms of political and international relations - surrounded by enemies, which is a recurring problem of political and military nature. Considering the set forth above reasons, and also new developing financial structures, the Republic Armenia moves ahead with small steps.

In comparison with 2008, showing fivefold growth of volumes of transactions, double growth of quantity of transactions, Насдак Оэмекс Armenia remains to one of the most active markets of corporate bonds [3].

During 2009, in exchange Bbond list included six bond issues, of which only four entered the lists, and the two moved from the free market Cbond.

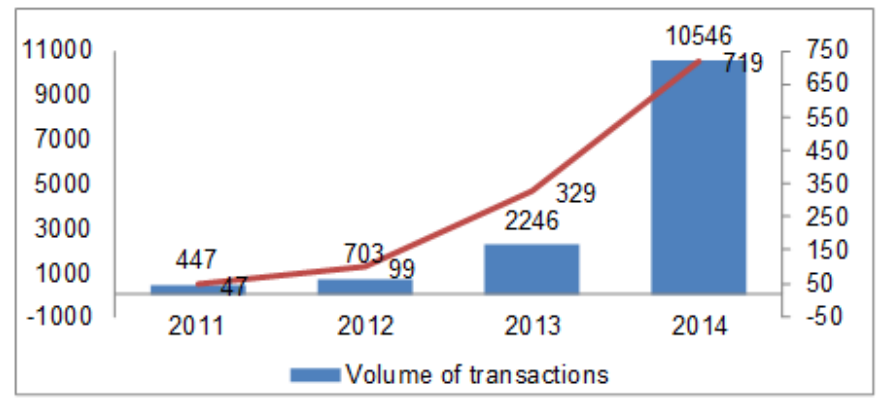

Fig. 1 Trade of Public Bonds in 2011-2014

During 2014, the corporate bond market has been concluded 719 transactions volume of 10.55 billion AMD, became the subject of trading corporate bonds 2,912,958 in 2012th 10 and 401,171 .

Below we present a market capitalization in 2005 to 2014.

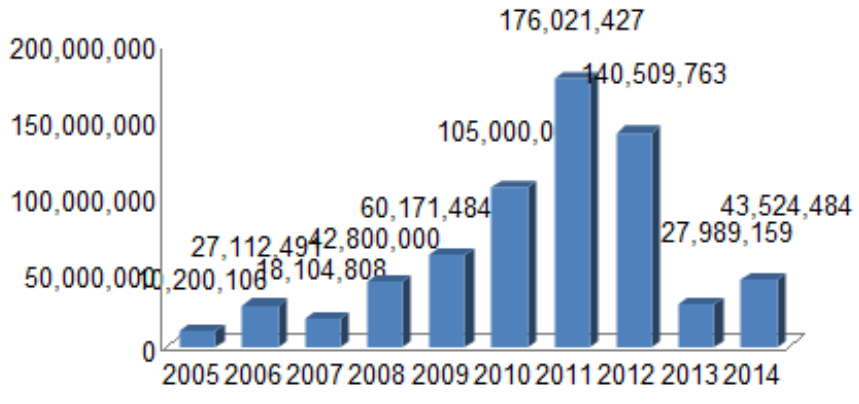

Fig. 2 Market capitalization 2005-2014 (US dollars)

In this scheme, we can notice that Armenia has the highest market capitalization 2011, amounting to U.S. \$ 176,021,427, and the lowest in 2005-10.200.106 dollars. The latter was due to the influence of the financial crisis in 2009, unfortunately, this crisis has shown that the system of governance of Economy - imperfect. Though number of developing countries have exceeded their prezhdnemu indicators.

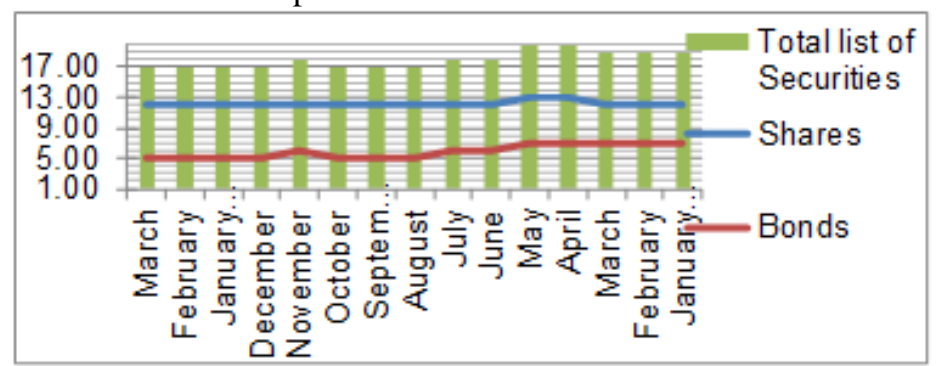

Fig.3. Securities fixed in lists of NASDAQ OMEX ARMENIA 2013-2014

Apparently from the schedule, since 2013 number of 
securities in RA, has changed slightly, and their total sum is so small, that it is impossible to compare to parameters of developing countries.

Now we shall present top five Armenian companies issuing shares under capitalization[4].

TABLE II

TOP FIVE ARMENIAN COMPANIES ISSUING SHARES UNDER CAPITALIZATION

\begin{tabular}{|c|c|c|c|c|}
\hline $\mathrm{N}$ & Issuers & & $\begin{array}{l}\text { Capitalization, } \\
\text { AMD }\end{array}$ & $\begin{array}{l}\text { Share, } \\
\%\end{array}$ \\
\hline 1 & Pure Iron Plant & $\begin{array}{l}\text { MQE } \\
\text { R }\end{array}$ & $\begin{array}{l}25.909 .875 .00 \\
0\end{array}$ & 48.12 \\
\hline 2 & $\begin{array}{l}\text { „Artsakh, } \\
\text { hydroelectric } \\
\text { power station }\end{array}$ & AHEK & $\begin{array}{l}12.034 .500 .00 \\
0\end{array}$ & 22.35 \\
\hline 3 & $\begin{array}{l}\text { "Ararat Bank" } \\
\text { OJSC }\end{array}$ & ARBK & 7.154 .406 .000 & 13.29 \\
\hline 4 & $\begin{array}{l}\text {,Armeconombank, } \\
\text {, OJSC }\end{array}$ & HEZB & 3.733 .340 .000 & 6.93 \\
\hline 5 & $\begin{array}{l}\text {,Armenian } \\
\text { Development } \\
\text { Bank,, OJSC }\end{array}$ & ZHBK & 3.170 .740 .000 & 5.89 \\
\hline & Other issuers & & 1.844 .313 .700 & 3.43 \\
\hline & Total & & $\begin{array}{l}53.847 .174 .70 \\
0\end{array}$ & \\
\hline
\end{tabular}

As we see, at present on parameters of capitalization in the market leader is Open Company Pure Iron Plant.

Thus, trade in actions at stock exchange is not developed. However, the stock exchange has a number of opportunities for regulation and developments of the given sphere.

\section{CONCLUSION}

Armenia's economic freedom score is 69.7, making its economy the 36th freest in the 2013 Index. Its overall score increased by 0.5 point from last year. Armenia is ranked 19th freest among the 43 countries in the Europe region, and its score puts it above the world and regional averages.

Armenia receives high marks in eight of the 10 economic freedoms. Over the past decade, market liberalization and privatization have recharged the economy. Despite the economic slowdown in recent years, a macroeconomic policy environment supported by low taxes and stable government spending has promoted steady economic growth. The regulatory framework is sound, and an open trade regime with low tariffs facilitates the free flow of goods.

Further growth in economic freedom in Armenia will require deeper institutional reforms that include better protection of property rights and strengthening of the judicial system. Corruption remains widespread in many sectors of the economy. Despite relatively low tax rates, tax evasion has become a growing concern [5].

Armenia has accelerated the pace of legal and regulatory reform to restructure its financial sector. Regulatory reforms have included adoption of international accounting standards, and many banks have closed or merged. The state no longer has a stake in any bank, and banks are all privately owned. Financial-sector infrastructure has been enhanced through improved market transparency. However, the banking sector, which accounts for over 90 percent of total financial-sector assets, still suffers from insufficient long-term funding and market segmentation. Capital markets and insurance are not fully developed. The securities market has a legal framework in place but remains small. Due to the limited external exposure of local banks, the global financial turmoil has not had a direct adverse impact on the financial system's stability.

\section{REFERENCES}

[1] Beck, Thorsten, Ross Levine, and Norman Loayza (2000). - Finance and the Sources of Growth. Journal of Financial Econ., 58, 2012. pp. 261-300

http://dx.doi.org/10.1016/S0304-405X(00)00072-6

[2] Conrad, Jurgen (2008),- Capital Markets in Central Asiall, ADB CWRD Discussion Paper, No.1

[3] www.cba.am

[4] National Statistic Service Republic of Armenia: Main Statistical Data. Yerevan, Armenia 2013. www.armstat.am

[5] www.caps.am. 